\title{
Efektivitas Penerbitan KIA (Kartu Identitas Anak) Melalui Aplikasi Dukcapil Smart Kabupaten
} Bantul Tahun 2019

\author{
Sitti Ajeng Nurqarimah Taliu', Suranto ${ }^{2}$ \\ ${ }^{1}$ Program Studi Ilmu Pemerintahan, Universitas Muhammadiyah Yogyakarta, Indonesia \\ ${ }_{2}^{2}$ Program Studi Ilmu Pemerintahan, Universitas Muhammadiyah Yogyakarta, Indonesia
}

\section{ARTICLE INFORMATION}

Received: July 20, 2020

Revised: October 26, 2020

Accepted: November 01, 2020

Available online: November 07, 2020

\section{KEYWORDS}

Effectiveness, Public Services, Management Information Systems

CORRESPONDENCE

Phone: +628136805366

E-mail: sittiajeng165@gmail.com

\section{A B S T R A C T}

Disdukcapil (Population and Civil Registration Service) of Bantul Regency based on Permendagri No.2 of 2016 concerning Child Identity Card to meet the identified needs of children, where KIA, in this case, is intended to be the same as KTP-EL, namely as a sign of population, the difference is KTP-EL is intended to be owned by people aged 17 years and over, while KIA is for children under 17 years of age. Through technological advances like today, the millennial era is of course very updated regarding various attractive offers such as discounts or information that are beneficial to millennials, for this reason, the Bantul Regency Disdukcapil seeks to maximize their performance to continue to support the number of KIA making, especially in Bantul Regency. The method used in this research is descriptive qualitative research. Based on the results found by researchers through the concept of effectiveness using 3 variables, namely Goal Achievement, Integration, and Adaptation. From the results of this study, the researchers concluded that the effectiveness of MCH issuance through the Dukcapil Smart application in Bantul Regency in 2019 is quite effective in making MCH through the Dukcapil Smart application but has not been effective in adapting $\mathrm{MCH}$ applications through the Dukcapil Smart application.

\section{PENDAHULUAN}

Teknologi merupakan bentuk perkembangan yang sangat pesat di seluruh dunia. Tanpa sadar seluruh masyarakat dituntut untuk mengetahui penggunaan teknologi baik secara smartphone ataupun komputer. Revolusi dalam bidang teknologi di Indonesia saat ini dapat dikatakan sangat berkembang baik, melalui revolusi inilah pemerintah melakukan perbaikan pada kinerja pemerintahan. Tak lepas dari meningkatnya teknologi maka pemerintah berupaya melibatkan peran masyarakat dalam kemajuan suatu daerah maupun wilayah. Hal ini tentunya mendorong pemerintah untuk terus berinovasi dalam bidang teknologi dan meningkatkan pemberian hak masyarakat yaitu pelayanan publik.

Pelayanan kepada masayarakat oleh Pemerintah semakin berkembang kearah E-government sebagai upaya untuk memberikan pelayanan kepada masyarakat khususnya pelayanan informasi serta penerapan good governance dalam menunjang aktivitas pemerintahan Sebagai bukti nyata dalam mewujudkan peningkatan kualitas khususnya di pelayanan publik secara bertahap agar tercapainya pelayanan publik yang prima (Reiza Macella, 2020; Wulanadary et al., 2019). Selain memberikan pelayanan public melalui e-government, pemerintah juga memberikan pelayanan melalui m-government. $\mathrm{M}$ government adalah penggunaan teknologi smartphone dalam administrasi pemerintah untuk memberikan pelayanan kepada masyarakat melalui smartphone. E-government dan m-government merupakan satu kesatuan inovasi yang dibentuk pemerintah dalam penerapan pelayanan publik, dimana m-government didasari oleh e-government. Kabupaten Bantul saat ini telah menerapkan sistem e-government dan m-government melalui aplikasi dan web untuk memberikan kemudahan bagi pengguna baik melalui aplikasi untuk melakukan pengajuan pelayanan ataupun web untuk mengetahui beberapa informasi publik.

Kebijakan Kartu Indentitas Anak sudah diterapkan dibergai daerah di Indonesia berdasarkan Permendagri No.2 tahun 2016 yang mewajibkan penduduk di bawah 17 tahun untuk memiliki KIA (Albar, 2018). Bandung, Lampung, semarang, kota Yogyakarta, Pontianak dan Denpasar adalah beberapa daerah yang sudah menerapkan kebijakan tersebut (Afrizal, 2017; Apriliani, 2020; Arista \& Suderana, 2019; Sri Hardjanto, 2019). Kebijakan Kartu Identitas Anak (KIA) di Dinas Kependudukan dan Pencatatan Sipil Kota Yogyakarta. Disdukcapil Kota Yogyakarta memberikan fasilitas diskon dan berbagai kemudahan untuk pelayanan publik. Kemudahan dan inovasi untuk memudahkan masayarakat secara sederhana dilakukan oleh pemerintah Kabupaten Aceh Barat dengan membentuk petugas registrasi gampong (PRG). PRG bertugas untuk mengurus adminduk masyarakat ke Disdukcapil (Ikhsan et al., 2020). Selain kota Jogyakarta KIA juga sudah diterapkan di Semarang dengan berbagai tantangan Pemerintah Daerah Kota Semarang dalam melaksanakan penerbitan KIA membuat PERDA No.4 Tahun 2016, namun pelaksanaannya pada tahun 2017. Keterlambatan pelaksanaan KIA karena masalah cakupan kepemilikan Akta Kelahiran anak yang masih kurang. Persiapan yang dilakukan Pemda Kota Semarang dalam rangka pelaksanaan KIA di tahun 2017 adalah mengumpulkan data anak-anak, membahas penambahan manfaat KIA dengan beberapa pihak dinas dan pihak swasta, melakukan studi 
banding ke daerah yang sudah melaksanakan KIA dan dasar pengaturannya (Sri Hardjanto, 2019).

Disdukcapil (Dinas kependudukan dan Pencatatan Sipil) Kabupaten Bantul berdasarkan Permendagri No.2 Tahun 2016 tentang Kartu Indentitas Anak dalam upaya memenuhi kebutuhan identitas anak yang dimana KIA dalam hal ini dimaksudkan bertujuan sama dengan KTP-EL, yaitu sebagai tanda kependudukan, bedanya KTP-EL ditujukan wajib dimiliki oleh masyarakat yang berusia 17 tahun ke atas, sedangkan KIA diperuntukkan bagi anak-anak di bawah umur 17 tahun. Melalui kemajuan teknologi seperti saat ini, era milenial tentunya sangat update terkait berbagai tawaran menarik seperti diskon ataupun informasi yang menguntungkan bagi kaum milenial, untuk itu Disdukcapil Kabupaten Bantul berupaya memaksimalkan kinerja mereka untuk terus menunjang angka pembuatan KIA khususnya di Kabupaten Bantul. Penelitian ini membahas tentang efektivitas dalam penerbitan Kartu Identitas Anak melalui aplikasi Dukcapil Smart dimana saat ini di launchingnya aplikasi tersebut guna mempermudah masyarakat mengurus Adminduk." Melihat dari latar belakang masalah yang diceritakan penulis, maka dirumuskan masalah yang akan dibahas dalam proposal ini, yaitu: Bagaimana efektivitas penerbitan KIA (Kartu Identitas Anak) melalui aplikasi Dukcapil Smart Kabupaten Bantul Tahun 2019? Tujuan penelitian untuk mengetahui bagaimana efektivitas penerbitan KIA (Kartu Identitas Anak) melalui aplikasi Dukcapil Smart Kabupaten Bantul Tahun 2019.

\section{METODE}

Pada penelitian ini, peneliti menggunakan jenis penelitian deskriptif kualitatif dimana dalam analisanya nanti berdasarkan kemampuan dan hasil telaah peneliti dalam menghubungkan fakta lapangan, informasi yang didapatkan dan data yang ada. Metode penelitian kualitatif digunakan sebagai prosedur dalam penelitian ini yang menghasilkan data deskriptif, yaitu menggambarkan fakta yang ditemukan di lapangan baik berupa tulisan ataupun lisan yang didapatkan dari berbagai sumber yang ditemui. Adapun teknik pengambilan sampel dalam penelitian ini menggunakan teknik Purposive Sampling yaitu dalam metode ini menggunakan kriteria yang telah dipilih oleh peneliti dalam memili sampel (Creswell, 2014; Sugiyono, 2012).

Teknik analisa dalam penelitian ini menggunakan analisa kualitatif, dimana data yang didapatkan diklarifikasikan dan digambarkan dengan kalimat yang mudah dipahami. Kemudian akan dianalisa berdasarkan objek yang diteliti dan akan ditafsirkan dengan data atau dasar teori yang sudah ada sehingga mampu dinilai hasilnya secara menyeluruh. Semua data diperoleh dari wawancara, naskah, dokumentasi, dokumen resmi yang bersifat pribadi dan dokumen lain yang mendukung keabsahan dalam memperoleh data penelitian (Creswell, 2014; Sugiyono, 2012).

\section{HASIL DAN PEMBAHASAN}

Masyarakat Suku Bajo dikenal sebagai manusia laut atau manusia perahu. Mereka menyebut diri mereka (termasuk Suku Bajo lainnya) dengan sebutan sama'. Sedangkan untuk orang lain (yang bukan merupakan Suku Bajo), Suku Bajo menyebutnya dengan istilah bagai. Dahulu, mereka tinggal di
Dinas Kependudukan dan Pencatatan Sipil Kabupaten Bantul berdasarkan Permendagri No. 7 Tahun 2019 terkait Adminduk Secara Daring maka seluruh administrasi kependudukan (Adminduk) di setiap daerah dilakukan secara daring/online (Sutanta \& Khabib, 2012) . Dimaksud dalam hal ini ialah bertujuan untuk menuju Go-Digital, dikarenakan melihat perkembangan zaman dimana hampir setiap masyarakat telah memiliki smartphone maka pada awal tahun 2019 Disdukcapil Kabupaten Bantul telah melaunching aplikasi Dukcapil Smart guna mempermudah pelayanan bagi masyarakat untuk mengurus Adminduk. Aplikasi Dukcapil Smart menyediakan 9 fitur pelayanan yang dapat diakses pelayanannya, adapun 9 fitur pelayanan seperti: KTP EL, KIA, Smart On, Akta Kelahiran, Akta Kematian, Akta Perkawinan, Akta Perceraian, Pindah Keluar dan Pindah Datang.

Pada Penelitian ini peneliti menggunakan tiga indicator yaitu, Pencapaian Tujuan, Integritas dan Adaptasi (Steer, 1985). Hasil dari pembahasan peneliti terkait Efektivitas Penerbitan KIA melalui aplikasi Dukcapil Smart di Kabupaten Bantul tahun 2019:

\section{Pencapaian Tujuan}

Pada penelitian ini peneliti berfokus pada kesesuaian penerbitan KIA (Kartu Identitas Anak) melalui aplikasi Dukcapil Smart apakah sudah sesuai dengan Permendagri No.7 Tahun 2019.

Paulus Eko Ananto, S.H,M.Sc selaku Kepala Seksi Identitas Penduduk mengungkapkan bahwa:

“...Dulu itu kalo mau buat KIA, orangtua harus datang ke Dukcapil Bantul dulu biar bisa mengajukan permohonan pembuatan KIA anak dengan melampirkan syarat-syarat yang sudah ada, namun sejak dilaunchingnya aplikasi Dukcapil Smart dan juga berdasarkan Permendagri No 2 Tahun 2016 tentang wajib memiliki KIA bagi anak usia di bawah 17 tahun dan berdasarkan Permendagri No.7 Tahun 2019 maka kami memberikan kemudahan pada masyarakat untuk membuat KIA tanpa harus datang ke Dukcapil Bantul yaitu dengan dilaunchingnya aplikasi Dukcapil Smart". (Wawancara, 13 Desember 2019).

Berdasarkan hasil wawancara di atas dapat ditelaah maksud dari narasumber ialah sejak diterbitkannya aplikasi Dukcapil Smart berdasarkan Permendagri No 7 tahun 2019 tentang Adminduk Secara daring/online, maka seluruh proses pengurusan administrasi kependudukan di Disdukcapil Kabupaten Bantul dilakukan secara online atau lebih tepatnya lebih mudah dilakukan hanya melalui smartphone. Dengan adanya aplikasi Dukcapil Smart yang menyediakan berbagai jenis pelayanan maka masyakarat khususnya yang ingin mengurus adminstrasi kependudukan seperti pengajuan pembuatan Kartu Identitas Anak (KIA) akan lebih mudah melalui aplikasi Dukcapil Smart.

Tabel 1. Daftar Narasumber Penelitian

\begin{tabular}{|c|c|c|c|}
\hline $\mathrm{NO}$ & NAMA & PEKERJAAN & ALAMAT \\
\hline 1 & Tati Latifah & $\begin{array}{c}\text { Ibu Rumah Tangga } \\
\text { (IRT) }\end{array}$ & Sedayu, Bantul \\
\hline 2 & Elva Warli & $\begin{array}{l}\text { IRT sekaligus } \\
\text { Karyawan Swasta }\end{array}$ & $\begin{array}{l}\text { Banguntapan, } \\
\text { Bantul }\end{array}$ \\
\hline 3 & Sri Pamularsih & $\begin{array}{c}\text { Pendamping Kasus } \\
\text { di Sentra Advokasi } \\
\text { Perempuan Difabel } \\
\text { dan Anak }\end{array}$ & Kasihan, Bantul \\
\hline 4 & Fahril Hidayat & Wiraswasta & Banguntapan \\
\hline
\end{tabular}




\begin{tabular}{|c|c|c|c|}
\hline 5 & $\begin{array}{l}\text { Raizaada } \\
\text { Balqist } \\
\text { Nurhalisa }\end{array}$ & $\begin{array}{l}\text { Pelajar (SMA N } 1 \\
\text { Sedayu) }\end{array}$ & Sedayu, Bantul \\
\hline 6 & Siti & $\begin{array}{l}\text { Ibu Rumah Tangga } \\
\text { (IRT) }\end{array}$ & Kasihan, Bantul \\
\hline 7 & Sulis & $\begin{array}{l}\text { Ibu Rumah Tangga } \\
\text { (IRT) }\end{array}$ & Soboman, Bantul \\
\hline 8 & $\begin{array}{c}\text { Heti } \\
\text { Purwaningsih }\end{array}$ & $\begin{array}{l}\text { PNS Pensiunan } \\
\text { Muhammadiyah }\end{array}$ & Kurahan, Bantul \\
\hline 9 & $\begin{array}{l}\text { Ribut Budi } \\
\text { Santoso }\end{array}$ & Wiraswasta & Pundong, Bantul \\
\hline 10 & Ardiyanto Arif & Security & Dlingo, Bantul \\
\hline 11 & $\begin{array}{c}\text { Rury } \\
\text { Handayani }\end{array}$ & ABM PT GSI & $\begin{array}{l}\text { Banguntapan, } \\
\text { Bantul }\end{array}$ \\
\hline 12 & Rindi & SMA N 1 Sedayu & Sedayu, Bantul \\
\hline 13 & $\begin{array}{c}\text { Ahmad Bharul } \\
\text { Shobib }\end{array}$ & Karyawan Swasta & $\begin{array}{l}\text { Banguntapan, } \\
\text { Bantul }\end{array}$ \\
\hline 14 & $\begin{array}{l}\text { Sulchan } \\
\text { Fathoni }\end{array}$ & Wiraswasta & $\begin{array}{c}\text { Banguntapan, } \\
\text { Bantul }\end{array}$ \\
\hline 15 & $\begin{array}{l}\text { Ilham } \\
\text { Adhitama }\end{array}$ & Teknisi Indihome & Pundong, Bantul \\
\hline
\end{tabular}

Tabel 2. Jumlah Anak usia di bawah 17 Tahun Kabupaten Bantul Tahun 2019

\begin{tabular}{ccc}
\hline JUMLAH & KECAMATAN & UMUR \\
\hline 7418 & Srandakan & $<=1$ tahun \\
7220 & Sanden & 2 tahun \\
7044 & Kretek & 3 tahun \\
8539 & Pundong & 4 tahun \\
9923 & Bambang Lipuro & 5 tahun \\
12.400 & Pandak & 6 tahun \\
9187 & Pajangan & 7 tahun \\
16.154 & Bantul & 8 tahun \\
14.717 & Jetis & 9 tahun \\
15.904 & Imogiri & 10 tahun \\
9392 & Dlingo & 11 tahun \\
30.429 & Banguntapan & 12 tahun \\
13.393 & Pleret & 13 tahun \\
13.943 & Piyungan & 14 tahun \\
25.545 & Sewom & 15 tahun \\
26.676 & Kasihan & 16 tahun \\
11.974 & Sedayu & 17 tahun \\
239.858 & TOTAL & $<1$ Th-17Th \\
\hline
\end{tabular}

Tabel 3. Jumlah Permohonan Cetak KIA Melalui Aplikasi Dukcapil Smart Bantul Tahun 2019

\begin{tabular}{cccc}
\hline No & Bulan & $\begin{array}{c}\text { Jumlah } \\
\text { Permohonan }\end{array}$ & Keterangan \\
\hline 1 & Januari & 0 & Aplikasi belum aktif \\
2 & Februari & 0 & Aplikasi belum aktif \\
3 & Maret & 0 & Aplikasi belum aktif \\
4 & April & 0 & Aplikasi belum aktif \\
5 & Mei & 6 & Aktif \\
6 & Juni & 28 & Aktif \\
7 & Juli & 47 & Aktif \\
8 & Agustus & 87 & Aktif \\
9 & September & 83 & Aktif \\
10 & Oktober & 61 & Aktif \\
11 & November & 11 & Aktif \\
12 & Desember & 19 & Aktif \\
\hline
\end{tabular}

Tabel 4. Jumlah Cetak KIA Kabupaten Bantul Tahun 2019

\begin{tabular}{ccc}
\hline NO & BULAN & Jumlah Cetak \\
\hline 1 & Januari & 4.024 \\
2 & Februari & 2.644 \\
3 & Maret & 2.554 \\
4 & April & 2.863 \\
5 & Mei & 3.511 \\
6 & Juni & 2.951 \\
7 & Juli & 5.407 \\
8 & Agustus & 7.955 \\
\hline
\end{tabular}

Sitti Ajeng Nurqarimah Taliu dan Suranto

\begin{tabular}{ccc}
\hline 9 & September & 16.095 \\
10 & Oktober & 18.457 \\
11 & November & 5.124 \\
12 & Desember & 3.947 \\
& Jumlah & 75.532 \\
\hline
\end{tabular}

Menelaah dari ketiga tabel di atas, dapat dilihat bahwa jumlah anak usia < 17 Tahun Kabupaten Bantul pada tahun 2019 berjumlah 239.858 anak dan pengajuan penerbitan Kartu Identitas Anak (KIA) pada aplikasi Dukcapil Smart pada tahun 2019 berjumlah 342 KIA yang diajukan melalui Aplikasi Dukcapil Smart sedangkan jumlah cetak KIA baik offline ataupun online di Disdukcapil ataupun Dukcapil Smart Kabupaten Bantul berjumlah 75.532 KIA. Jumlah ini tentunya sangat jauh berbeda dari target Disdukcapil Kabupaten Bantul dalam penerbitan KIA melalui aplikasi Dukcapil Smart. Dengan adanya aplikasi Dukcapil Smart yang dilaunchingkan Disdukcapil Kabupaten Bantul seharusnya menghasilkan lebih banyaknya penerbitan KIA melalui aplikasi Dukcapil Smart dibandingkan jumlah cetak KIA keseluruhan. Aplikasi Dukcapil Smart tentunya diharapkan dapat memudahkan masyarakat Kabupaten Bantul dalam mempermudah pelayanan administrasi penduduk secara daring (Zainuddin, 2019). Untuk itu disimpulkan bahwa Aplikasi Dukcapil Smart yang dibuat oleh Disdukcapil Kabupaten Bantul dapat dinilai kurang efektif dalam penerbitan KIA melalui aplikasi Dukcapil Smart Kabupaten Bantul.

Aplikasi Dukcapil Smart merupakan suatu aplikasi yang telah terintegrasi menjadi pelayanan yang mencakup berbagai pelayanan yang disediakan oleh Dinas Kependudukan dan Pencatatatan Sipil Kabupaten Bantul. Pada aplikasi Dukcapil Smart terdapat fitur KIA (Kartu Identitas Anak) yang dimana KIA berdasarkan Permendagri Nomor 2 Tahun 2016 tentang Kartu Identitas Anak wajib dimiliki penduduk yang berusia dibawah 17 tahun sebagai kartu identitas anak. Program yang dibuat KIA tentunya harus menarik perhatian masyarakat untuk mengajukan penerbitan KIA melalui aplikasi Dukcapil Smart.

Berdasarkan telaah peneliti dari hasil pembahasan di atas dapat disimpulkan bahwa penerbitan KIA melalui aplikasi Dukcapil Smart sudah sesuai dengan Permendagri Nomor 7 tahun 2019 yaitu dilakukannya administrasi kependudukan secara daring/online.

Setelah dilaunching aplikasi Dukcapil Smart maka Disdukcapil Kabupaten Bantul pastilah memiliki input dan output dari penerbitan KIA melalui aplikasi Dukcapil Smart untuk menilai seberapa efektif adanya aplikasi Dukcapil Smart dalam hal penerbitan Kartu Identitas Anak (KIA). Input dalam hal ini dimaksudkan ialah prosess penerbitan KIA melalui aplikasi Dukcapil Smart, dimana jumlah pengajuan penerbitan Kartu Identitas Anak akan di ajukan melalui aplikasi dan dari Disdukcapil Kabupaten Bantul akan memproses pengajuan masyarakat yang diajukan melalui aplikasi Dukcapil Smart. Sedangkan yang dimaksud output dalam hal ini ialah output penerbitan KIA melalui aplikasi Dukcapil Smart berupa Kartu Identitas Anak yang dimana setelah pengajuan penerbitan melalui aplikasi Dukcapil Smart telah selesai di proses maka anak atau orangtua yang mewakili tinggal menunggu KIA tersebut dikirim ke Kelurahan, Kecamatan atau Desa. 


\section{Integritas}

Aplikasi Dukcapil Smart merupakan suatu aplikasi yang telah terintegrasi menjadi pelayanan yang mencakup berbagai pelayanan yang disediakan oleh Dinas Kependudukan dan Pencatatatan Sipil Kabupaten Bantul. Pada aplikasi Dukcapil Smart terdapat fitur KIA (Kartu Identitas Anak) yang dimana KIA berdasarkan Permendagri Nomor 2 Tahun 2016 tentang Kartu Identitas Anak wajib dimiliki penduduk yang berusia dibawah 17 tahun sebagai kartu identitas anak. Program yang dibuat KIA tentunya harus menarik perhatian masyarakat untuk mengajukan penerbitan KIA melalui aplikasi Dukcapil Smart.

Gambar 1. Warga Bantul Menerima KK, KIA, Akta Kelahiran pengajuan melalui aplikasi Dukcapil Smart

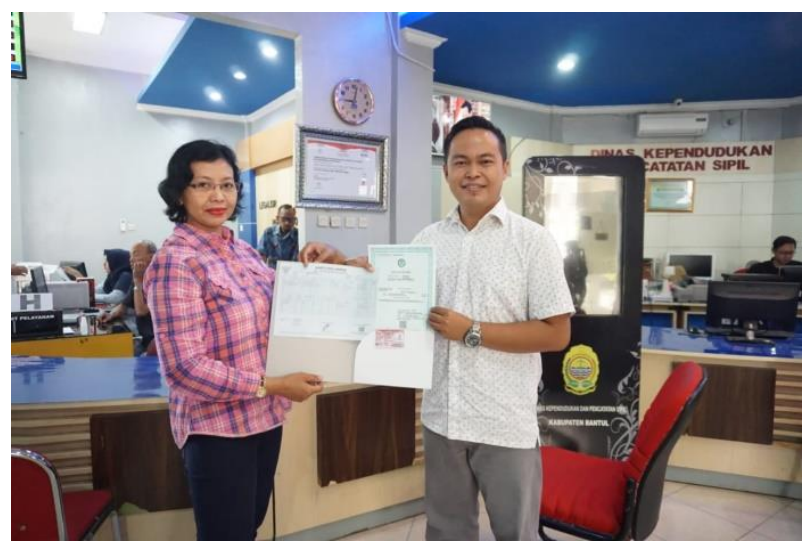

Adapun proses dalam penerbitan KIA melalui aplikasi Dukcapil Smart berdasarkan dengan ketepatan dari suatu prosedur yang berlaku. Proses penerbitan KIA melalui aplikasi Dukcapil Smart dalam hal ini cukup dengan melampirkan beberapa persyaratan sesuai prosedur yang diberlakukan oleh Disdukcapil Kabupaten Bantul. Adapun proses pengajuan untuk pembuatan Kartu Identitas Anak melalui aplikasi Dukcapil Smart cukup melampirkan Akta kelahiran, Kartu Keluarga, KTP orangtua dan akan diproses selama 1-2 hari. Lebih mudahnya lagi, kita hanya perlu mengajukan permohonan penerbitan KIA melalui aplikasi Dukcapil Smart dari rumah dan dapat memantau proses KIA di halaman depan KIA. Setelah proses selesai, maka KIA dapat diambil di Disdukcapil Kabupaten Bantul. Bagi yang rumahnya jauh, maka Disdukcapil Kabupaten Bantul akan mengirim KIA yang telah diterbitkan ke Kecamatan, Desa atau Kelurahan yang bersangkutan.

Berdasarkan Permendagri No.2 Tahun 2016 tentang Kartu Identitas Anak bahwa semua anak yang usianya 17 Tahun wajib memiliki KIA sebagai kartu identitas mereka. KIA bagi anak sama halnya seperti KTP yang wajib dimiliki masyarakat berusia >17 Tahun. Masyarakat di Kabupaten Bantul telah mengindahkan Peraturan Pemerintah Kabupaten Bantul dengan membyat KIA untuk anak mereka. Setelah Disdukcapil Kabupaten Bantul melaunching aplikasi Dukcapil Smart maka semakin mudah pula peluang bagi masyarakat Kabupaten Bantul untuk mengurus administrasi secara daring. Proses penerbitan KIA melalui aplikasi Dukcapil Smart seperti yang telah dibahas peneliti di atas dapat disimpulkan bahwa penerbitaan KIA melalui aplikasi Dukcapil Smart sudah sangat efisien melihat dari proses ketepatan waktu yang ditentukan.
Adaptasi

Pelayanan yang di berikan Pemerintah Pusat melalui OPD seperti Dinas Kependudukan dan Pencatatan Sipil Kabupaten Bantul tentunya tidak terhindar dari adanya kendala dalam proses pelayanan (Irwantoro, 2018). Namun kendala yang ada tentunya tidak membuat Disdukcapil Kabupaten Bantul menyerah untuk mengatasi berbagai kendala yang dihadapinya. Untuk itu diperlukannya suatu ide atau inovasi dari OPD dalam meningkatkan kualitas pelayanan. Dalam pengelolaan proses pelayanan tentunya diperlukan adaptasi pelaksanaan program, seperti pelayanan penerbitan Kartu Identitas Anak yang awal pengurusannya harus mendatangi Disdukcapil Kabupaten Bantul untuk melakukan pengajuan administrasi kependudukan, hal ini tentunya memerlukan waktu luang agar menyempatkan datang ke Disdukcapil Kabupaten Bantul melakukan administrasi tersebut. Untuk itu, Disdukcapil Kabupaten Bantul mempunyai cara dengan membuat aplikasi Dukcapil Smart agar memudahkan pelayanan administrasi bisa digunakan masyarakat secara daring.

\section{KESIMPULAN}

Berdasarkan keseluruhan hasil penelitian pada bab pembahasan di atas, maka penelitian yang dilakukan dengan judul "Efektivitas Penerbitan KIA Melalui Aplikasi Dukcapil Smart Kabupaten Bantul Tahun 2019”. Peneliti menyimpulkan bahwa:

Kesesuaian penerbitan KIA melalui aplikasi Dukcapil Smart apakah sesuai dengan Permendagri No. 7 Tahun 2019. Meninjau dari hasil pembahasan peneliti yang telah dijelaskan di atas, maka dapat disimpulkan terkait kesesuaian penerbitan KIA melalui aplikasi Dukcapil Smart bahwa telah sesuai dengan Permendagri Nomor 7 tahun 2019 tentang administrasi kependudukan dilakukan secara daring. Masyarakat tidak perlu lagi datang ke Disdukcapil Kabupaten Bantul untuk mengantri dalam hal proses pengajuan penerbitan KIA. Hal ini tentunya dapat dikatakan sudah efektif dalam hal kesesuaian penerbitan KIA melalui aplikasi Dukcapil Smart.

-Input dan Output dari penerbitan KIA melalui aplikasi Dukcapil Smart. Menelaah dari data yang telah dipaparkan peneliti pada point kedua indikator pertama dijelaskan bahwa jumlah usia anak < 17 tahun berjumlah 239.858 jiwa sedangkan penerbitan KIA melalui aplikasi Dukcapil Smart berjumlah 342 Kartu Identitas Anak. Hal ini tentunya dapat disimpulkan bahwa penerbitan KIA melalui aplikasi Dukcapil Smart belum efektif. Mengapa demikian? Dikarenakan masyarakat melakukan pengajuan pembuatan KIA secara kolektif ataupun datang langsung ke Disdukcapil Kabupaten Bantul. Penerbitan KIA di Disdukcapil Kabupaten Bantul berjumlah 75.532 Kartu anak. Menelaah dengan adanya pelayanan penerbitan KIA melalui aplikasi Dukcapil Smart dinilai belum efektif.

-Proses dalam penerbitan KIA melalui aplikasi Dukcapil Smart berdasarkan dengan ketepatan dari suatu prosedur. Menelaah dari hasil pembahasan peneliti di atas dapat disimpulkan bahwa proses dalam penerbitan KIA melalui aplikasi Dukcapil Smart berdasarkan dengan ketepatan dari suatu prosedur dinilai sudah sangat efektif. Dikarenakan proses dalam pengajuan penerbitan KIA melalui aplikasi Dukcapil Smart dapat dikatakan cukup cepat dengan durasi 1-2hari.

-Sosialiasi terhadap masyarakat terkait penerbitan KIA melalui aplikasi Dukcapil Smart. Menelaah dari hasil pembahasan peneliti di atas maka terkait sosialisasi terhadap 
masyarakat tentang penerbitan KIA melalui aplikasi Dukcapil Smart dapat disimpulkan bahwa sosialisasi dari Disdukcapil Kabupaten Bantul terhadap penerbitan KIA melalui aplikasi Dukcapil Smart dinilai belum efektif. Dikarenakan melihat dari jumlah antusias masyarakat dalam menggunakan pelayanan penerbitan KIA melalui aplikasi Dukcapil Smart.

-Adanya suatu inovasi atau terobosan oleh pihak Disdukcapil Bantul dalam menciptakan pelayanan yang baik dan benar. Dalam hal ini dapat disimpulkan terkait inovasi Disdukcapil Kabupaten Bantul yaitu telah dilaunching-nya aplikasi Dukcapil Smart untuk mempermudah masyarakat Kabupaten Bantul dalam melakukan administrasi kependudukan tanpa harus datang ke Disdukcapil Kabupaten Bantul mengantri. Hal ini tentunya dapat dikatakan efektif terkait terobosan yang dibuat oleh Disdukcapil Kabupaten Bantul.

-Penerbitan KIA melalui aplikasi Dukcapil Smart dapat di akses oleh masyarakat. Aplikasi Dukcapil Smart yang dibuat oleh Disdukcapil Kabupaten Bantul tentunya dapat diakses oleh masyarakat. Namun, yang dapat mengakses aplikasi Dukcapil Smart ini ialah masyarakat yang berdomisili di Kabupaten Bantul. Adapun pengaksesan dalam penerbitan KIA melalui aplikasi Dukcapil Smart dapat diakses oleh satu KK. Untuk login aplikasi Dukcapil Smart diperlukan satu KK dan satu NIK. Jika ada keluarga pihak lain yang menggunakan KK tersebut dan berbeda NIK maka tidak dapat login dikarenakan KK tersebut sudah dipakai oleh keluarga lainnya. Kesimpulan dari point ini ialah hal ini tentunya tidak efektif karena masih adanya kendala pada saat ingin login menggunakan l KK (Kartu Keluarga) yang telah digunakan oleh keluarga lainnya. Hal ini tentunya juga menjadi keluhan bagi masyarakat yang ingin menggunakan aplikasi Dukcapil Smart namun harus login dengan KK yang berbeda.

\section{REFERENSI}

Apsari, N. C. (2015). Hak Anak: Perspektif Pekerjaan Sosial. UNPAD Press.

Bendtsen, P., Damsgaard, M. T., Huckle, T., Casswell, S., Kuntsche, E., Arnold, P., de Looze, M. E., Hofmann, F., Hublet, A., Simons-Morton, B., ter Bogt, T., \& Holstein, B. E. (2014). Adolescent alcohol use: A reflection of national drinking patterns and policy? Addiction, 109(11), 1857-1868. https://doi.org/10.1111/add.12681

Castro, E. P.-D., Camacho, A. Z. V, Balanon, F. A. G., Yacat, J. A., Galang, M. T., \& Ong, M. G. (2005). Handbook for Social Workers on Basic Bio-Psychosocial Help for Children in Need of Special Protection. UNICEF.

Djusfi, A. R. (2019). Kedudukan Dan Fungsi Komisi Perlindungan Anak Indonesia Dalam Melindungi Hak-Hak Anak. Jurnal Public Policy, 2(2), 152-158. https://doi.org/10.35308/jpp.v2i2.763

Feinstein, E. C., Richter, L., \& Foster, S. E. (2012). Addressing the critical health problem of adolescent substance use through health care, research, and public policy. Journal of Adolescent Health, 50(5), 431-436. https://doi.org/10.1016/j.jadohealth.2011.12.033

Fikawati, S., Syafiq, A., \& Veratamala, A. (2017). Gizi Anak dan Remaja. PT RajaGrafindo Persada.

Ilhamsyah, F., Tjoetra, A., \& Ikhsan, I. (2020). Larangan Merokok di Mata Mahasiswa: Studi Tentang Kebijakan
Larangan Merokok di Tempat Umum. Jurnal Public Policy, 6(1), 31-34. https://doi.org/10.35308/jpp.v6il.1610

John W. Santrock. (2012). LIFE-SPAN Development (13th ed.). In McGraw-Hill.

Kemenkes RI. (2013). Riset Kesehatan Dasar (Riskesdas) 2013. Kementerian Kesehatan Republik Indonesia.

Kemenkes RI. (2018). Riset Kesehatan Dasar (Riskesdas) 2018. Kementerian Kesehatan Republik Indonesia.

Koentjaraningrat. (1990). Pengantar Ilmu Antropologi. Rineka Cipta.

Kumari, R., Bharti, R. K., Singh, K., Sinha, A., Kumar, S., Saran, A., \& Kumar, U. (2017). Prevalence of iron deficiency and iron deficiency anaemia in adolescent girls in a tertiary care hospital. Journal of Clinical and Diagnostic Research, 11(8), 4-6. https://doi.org/10.7860/JCDR/2017/26163.10325

Lestari, P., Widardo, W., \& Mulyani, S. (2016). Pengetahuan Berhubungan dengan Konsumsi Tablet Fe Saat Menstruasi pada Remaja Putri di SMAN 2 Banguntapan Bantul. Jurnal Ners Dan Kebidanan Indonesia, 3(3), 145-149. https://doi.org/10.21927/jnki.2015.3(3).145-149

Lovato, C. Y., Zeisser, C., Campbell, H. S., Watts, A. W., Halpin, P., Thompson, M., Eyles, J., Adlaf, E., \& Brown, K. S. (2010). Adolescent smoking: Effect of school and community characteristics. American Journal of Preventive Medicine, 39(6), 507-514. https://doi.org/10.1016/j.amepre.2010.08.019

Notoatmodjo, S. 2014. I. P. K. J. R. C. (2014). Kesehatan Masyarakat Ilmu \& Seni. Jakarta: Rineka Cipta. In Rineka Cipta :Jakarta.

Pesiwarissa, P. E., Messakh, S. T., \& Panuntun, B. (2019). Gambaran Implementasi Program Kesehatan Reproduksi Remaja di Puskesmas Getasan. Jurnal Keperawatan Respati $\begin{array}{lll}\text { Yogyakarta, } & 6(2), & 570-574 .\end{array}$ https://doi.org/10.35842/jkry.v6i2.314

Rachman, R. F. (2019). Implementasi Kebijakan Pusat Konseling Anak Dan Remaja Di Surabaya. Al-Tazkiah: Jurnal Bimbingan Dan ..., 8(2), 77-91. https://journal.uinmataram.ac.id/index.php/altazkiah/articl e/view/1217

Ranjabar, J. (2006). Sistem Sosial Budaya Indonesia: Suatu Pengantar. Penerbit Ghalia Indonesia.

Roscoe, A. (2012). International Development Policy and Practice: The Translation of a Children's Rights-Based Approach. In ProQuest Dissertations and Theses. http://search.proquest.com.ezproxy.library.uvic.ca/docview /1034118623? accountid=14846\%0Ahttp://lg5jh7pa3n.search. serialssolutions.com/directLink?\&atitle=International+Dev elopment+Policy+and+Practice $\% 3 \mathrm{~A}+$ The+Translation + of + a +Children\%27s+Rights-Based+Approa

Sacharin, R. M. (1994). Prinsip Keperawatan Pediatrik. Penerbit Buku Kedokteran EGC.

Safrida, S., \& Maulida, D. (2020). Kebijakan Pemerintah dalam Menanggulangi Kekerasan Seksual Anak di Bawah Umur (Studi di Kabupaten Aceh Utara). Jurnal Public Policy, 6(1), 45-50. https://doi.org/10.35308/jpp.v6il.1765

Sani, A. (2015). Pemidanaan Anak Menurut Hukum Islam Dan Hukum Pidana Indonesia. Jurnal Public Policy, 1(1), 1-10. https://doi.org/10.35308/jpp.v0i0.702

Sulistyaningsih. (2011). Metodologi Penelitian: Kebidanan 
(Kuantitatif-Kualitatif). Graha Ilmu.

Tisak, M. S., Tisak, J., Chen, Y., Fang, Q., \& Baker, E. R. (2017). Adolescent Misconduct Behaviors: A Cross-Cultural Perspective of Adolescents and Their Parents. Journal of Cross-Cultural Psychology, 48(2), 155-167. https://doi.org/10.1177/0022022116681844

UNICEF. (2010). Progress for Children: A Report Card for Adolescents (Issue 9).

Willis, S. S. (2017). Remaja \& Masalahnya. Penerbit Alfabeta.

Zare, E., Simbar, M., Shahhosseini, Z., \& Alavi Majd, H. (2017). The Priorities of Iranian Male Adolescents Health Needs. American Journal of Men's Health, 11(4), 1255-1259. https://doi.org/10.1177/1557988317693346 